\title{
Financial Performance of Islamic Banks in Turkey and the United Kingdom: A Comparative Study
}

\author{
Prof. Dr. Turan Ondes, Lecturer \\ Almabrok F. Ahmid (PhD), Student \\ Abdullah Faraj (PhD), Student
}

Faculty of Economics and Administrative Sciences,

Department of Business Administration (Accounting and Finance),

Ataturk University, Erzurum, Turkey

\begin{abstract}
Islamic banks are financial institutions just like conventional banks. However, Islamic banks do not deal with interest and are based on participation. These institutions raise funds and employ them within the scope of Islamic (Shariah) principles where the bank and the depositor share the business, thus sharing the profits and losses. This paper focuses on making a comparative between three Islamic banks in Turkey and five Islamic banks in the United Kingdom in terms of financial performance. More so, it aims to investigate whether or not Islamic banks in Turkey are more profitable, less risky, liquid, operationally efficient, and have a good management quality compared to the Islamic banks in UK. The time span used in this study is one period. The period is four years from 2013 until 2016. Our study used time series data (pooled Least Squares) (PLS) as panel regression on nine financial ratios (CAMEL) to examine the financial performance of these banks according to their profitability, Capital adequacy, Asset quality (riskiness and solvency), Management quality, Earning diversification (operationally efficient), and Liquidity. However, our results are insignificant for UK and significant in Turkey in terms of asset quality and management quality.
\end{abstract}

Keywords: Islamic banking, Financial Performance, Pooled OLS, Panel regression

\section{Introduction}

These days' Islamic banks have a place in the world economy. Islamic banks took their rules and regulations based on Islamic law and (Sariah) principle which prohibited the interest (Riba) in any financial transactions (Memon, 2007; Mirakhor, 2000;Hague, 2007). According to Dusuki (2008), 
Islamic banks exist in many countries (Muslim and non-Muslim) and are counted as alternative for conventional banks. Also, it has become one of the fastest grown sectors in the last four decades by 15 to 20 percent every year. Thus, it had reached 2.1 trillion at the end of 2014 (Kamik, 2014).

According to Henry and Wilson (2004), the first Islamic bank or institution was with free interest: Mit-Ghamr Saving Bank (1963) and followed by Nasser Social Bank (1970) in Cairo, Egypt. According to Siddiqi (2006), Dubai Islamic Banks were established in UAE in the 1970s. In 1975, Islamic development banks were also created in the same decade to support Muslim countries and communities, and it was created by the Muslim world. In the 1980s, many Islamic banks were established around the world.

\section{The History of Islamic Banks in Turkey}

In Turkey, there are five Islamic banks now: albaraka katılım bank was founded in 1984, Kuveyt Türk katılım bank was founded in 1989, Türkiye Finans katılım bank was founded in 2005, and lastly ziraat katılım bank and Vakıf katılım bank were founded recently in 2015. Figure 1 shows the Islamic banks in Turkey (Total asset in millions USD) from BankFocus (Bankscope) 2017. It shows that Kuvet Turk bank has the highest total asset by 13,749 million USD.

Figure 1.

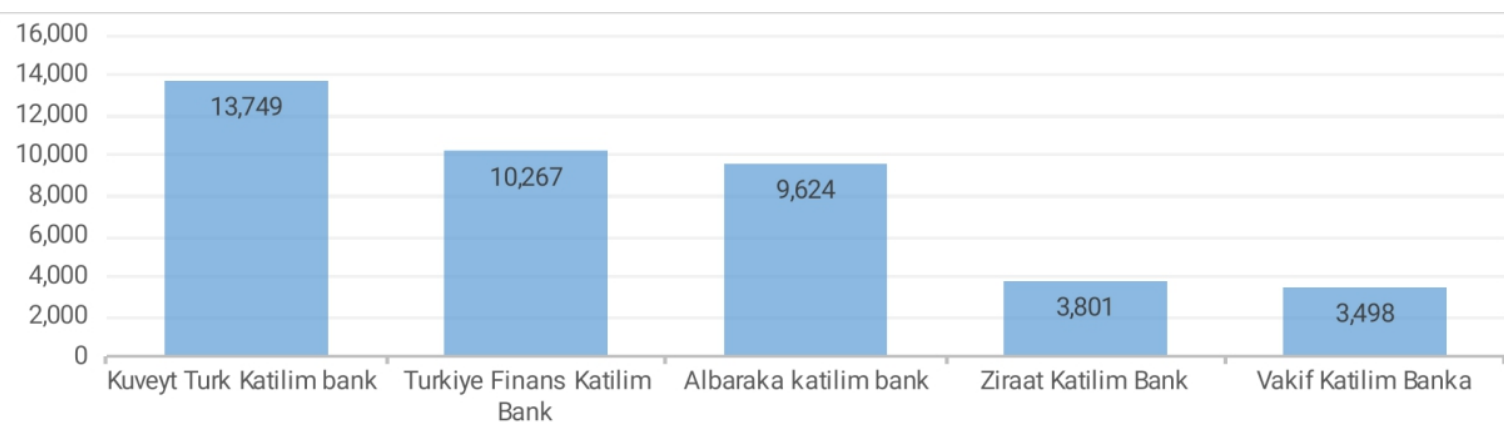

\section{The History of Islamic Banks in the UK}

In the UK, there are five Islamic banks: Rasmala was founded in 1999, QIB (UK) was founded in 2003, Al Rayan Bank was founded in 2004, Bank of London and The Middle East (BLME) were founded in 2006, and Gatehouse Bank was founded in 2008. Figure 2 shows the Islamic banks in the UK (Total asset in million USD) from BankFocus (Bankscope) 2017. It shows that Al Rayan bank has the highest total asset by 2,441 million USD. 
Figure 2.

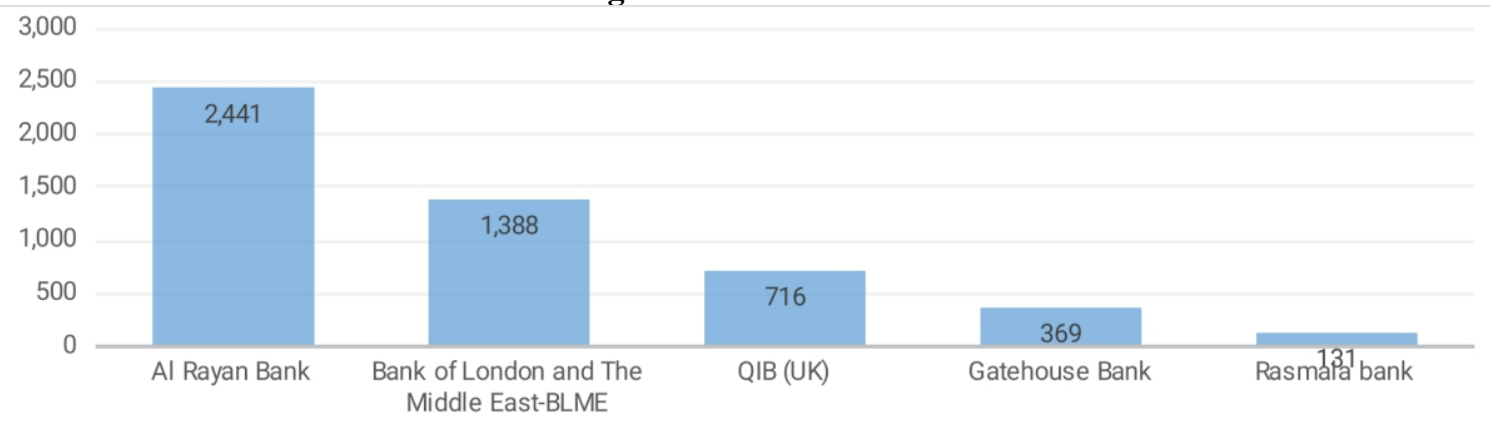

There are too many literatures about performance of banks that are the same which compare Islamic banks with the conventional banks. Nevertheless, few studies founded have examined the performance of Islamic banks from different countries. None of these studies compared a country such as the UK, where the majority of the populations are non-Muslim and which has a strong economy system, with Turkey which has less strength of economy than UK. On the other hand, the majority of the populations are Muslims.

\section{Objectives}

(1) To compare the performance of Islamic banks in both Turkey and the UK.

(2) To identify and indicate the financial health of Islamic banks in both Turkey and the UK.

(3) To analyze the performance of Islamic banks in Turkey and the UK.

The study compared the performance of Islamic banks in Turkey and United Kingdom (UK) in the period from 2013 to 2016. This was done by using time series data (pooled Least Squares) (PLS) panel regression. Three Islamic banks in Turkey and five Islamic banks in the UK were selected. There were nine financial ratios calculated from BankFocus, which will be estimated to measure the financial performance in terms of their profitability, capital adequacy, asset quality (riskiness and solvency), management quality, earning diversification (operationally efficient), and liquidity. The study made an attempt to fill a gap in the research area; to cover the Islamic banks in Turkey and the UK; indicate the financial health of modern economy; and provide clear representation of the financial position of banks to shareholders, management, and investors.

Consequently, our paper is divided into five sections: introduction, main literature Summary, Data and Methodology, Results and Discussion, and conclusion. 


\section{Literature Review}

Most past studies have evaluated the financial performance of Islamic and conventional banks with comparative way either through theoretical or empirical evidence. Moreover, most of these studies are located in Muslim countries.

According to Bashir (2001), the study examined the performance of Islamic banks in eight countries which is located in the Middle East and that was the period between 1993 until 1998. The performance is measured in terms of profitability and efficiency by using different internal and external banking characteristics. The result shows that high leverage and large loans to asset ratios leads to higher profitability. Also, the banks that are owned by foreigners are more profitable than the local ones. Furthermore, the taxes which are implicit and explicit have negative effect on the performance of the banks. On the other hand, macroeconomic conditions have positive impact, while the stock market completes the bank financing.

Brown (2003) examined the performance of Islamic banks in different countries by using Data Envelopment Analysis (DEA) from 1998 until 2001. The results showed that the most efficient markets in Iran and Brunei concentrated in Islamic banking markets are above 40 percent and the potential growth of Islamic banks is massive. However, in Yemen, the growth rate was from 9.4 percent in 1998 to 19.2 percent in 2001. Indonesia and Sudan are considered the last in the growth phase. In terms of liquidity, Bahamas has the most liquid, while Tunisia and Kuwait have the lowest.

Samad and Hassan (1999) examined the performance of Islamic bank called

Bank Islam Malaysia Berhad (BIMB) in both interbank and intertemporal in the period 1984 until 1997. The performance of BIBM was compared to 8 conventional banks in terms of profitability, liquidity, risk and solvency, and community involvement. They used T-test and F-test. The study found that BIMB is less risky and more liquid when compared to 8 conventional banks.

Azhar Rosly and Afandi Abu Bakar (2003) examined the performance of Islamic and mainstream banks (conventional banks) in Malaysia and they used T-test and descriptive statistics. The result showed that conventional banks are better than Islamic banks in terms of efficiency in the period from 1996 until 1999. However, the expansion for conventional banks have larger market size, long-term experience, and financial deepening factor. This has not been developed yet by Islamic banks.

According to Sundas Ayub and Mumtaz (2012), Augmented DickeyFuller (ADF) and correlogram tests were used to analyze the data collected from Islamic bank (Al-Baraka Bank) and conventional banks (five banks i.e. MCB, NBP, UBL, HBL) in Pakistan from 2001-2007. This was done to examine their performance, and the variables that were used include Net 
investment, Advances Net, Operating Foxed assets, Borrowing from Financial Institutions, Deposits and other Accounts, Administrative Expenditures, Profit and Number of Employees. The study showed that Al-Baraka bank was less profitable compared to conventional banks. Also, the study revealed that conventional banks have long history and experience. On the other hand, Islamic bank just started a few years ago which can make the comparative study unfair.

Ansari and Rehman (2011) examined the performance of five Islamic banks and compared them to five conventional banks in Pakistan from the period of 2005 until 2009. Return on assets (ROA) was used as proxy; descriptive statistics, correlation matrix and F-value were also used. The result showed the deposits of Islamic banks more than conventional banks which mean that there is an increase in the profitability of Islamic banks. On the other hand, Islamic banking system is much better than conventional banks and it has the ability to increase the market share by making new activities in Pakistan.

Hasan and Dridi (2011) evaluated the performance of Islamic and conventional banks in 2008. In other words, during the financial crises they examined the effect of the crises in terms of profitability, credit, and asset growth. The sample was taken from 120 Islamic and conventional banks in different areas, including all GCC countries except Oman, Turkey, and Malaysia. Seven ratios were used in this study. The study showed that conventional banks were affected differently from Islamic banks and this led to some factors of Islamic banks models as a result of bad and weak risk management. The Islamic banks had huge decline in profit in 2009, but however had better credit and asset growth. On an average, Islamic banks in the financial crises were better than the conventional banks.

Sehrish et al. (2012) stated that in order to examine the performance of Islamic and conventional banks, the study used six ratios from 2007 until 2011 in Pakistan. However, the result did not show huge differences in terms of the profitability of both banking sectors. On the other hand, Islamic banks are faced with less risk in regards to loans. They are also less efficient in expense management despite their increase in revenues from 2007 until 2011.

Amjad et al. (2013) opined the use of T-test and ANOVA to examine the performance of four Islamic and conventional banks in Pakistan within the period of 2008 until 2011. Thirteen ratios were used in terms of profitability, liquidity, risk and solvency, as well as capital adequacy. Furthermore, data were collected from annual reports of balance sheet and income statement. Interestingly, the result showed that Islamic banks are more prone to liquidity, less risky, and are operationally efficient than conventional banks.

In a study conducted on 21 commercial banks in Malaysia within the period from 1998 until 2009, How et al. (2005) examined the effect of the 
dollar collapse as a result of the US Sub-prime crisis on the return of assets. Thus, this proves that the Islamic banking model is an alternative to deal with the current financial crisis.

Johnes et al. (2014) compared the performance of Islamic and conventional banks in 18 countries within the period of 2004-2009. The result showed that there is no significant difference in regards to mean efficiency between both. However, the Islamic banks are less efficient than the conventional banks. Consequently, they should upgrade to a more standardized system of banking. On the other hand, conventional banks by examining, for example, the ongoing bonus culture, focuses on investigating why their managers are apparently underperforming relative to those in Islamic banks.

Hawaldar et al. (2017) examined the performance of 19 Islamic banks compared to 13 conventional banks in Bahrain over 5 years from 2010 until 2014. Financial performance tools such as profitability, liquidity, and solvency was used. The result showed that there is no significant difference between the performance of Conventional Banks and Islamic Banks. Moreover, there is no major difference in the profitability and liquidity performances in both banks. There is also a clear evidence of the strength of Islamic banks in recent financial downturn. Interestingly, the study showed that the principles of Islamic banks are more stable than conventional banks. Therefore, Islamic banks are better in terms of financial stability.

Rahman and Rosman (2013) examined the performance of 63 Islamic banks in Middle Eastern and North African (MENA) countries including Gulf Cooperation Countries (GCC) and Asian countries for four years from 2006 until 2009. The performances were examined by using data envelopment analysis based on the intermediation approach. The result showed that Islamic banks from Asian countries are more efficient than the MENA countries. Furthermore, most of the efficient Islamic banks were from GCC countries and the economic condition was the main determinant of measuring efficiency.

Yildirim (2015) compares the financial efficiency of four Islamic banks operating in Turkey and thirteen Islamic banks operating in Malaysia between the period of 2010 until 2014. The study showed that Scale inefficiency is the major reason behind the technical inefficiency of Islamic banks. Moreover, Islamic banks are not operating on an optimal scale.

\section{Data and Methodology}

The financial performance of banks is examined in many studies. In this study, the ratios and data were collected form BankFocus (Bankscope) from 2013 to 2016 from Islamic banks in both Turkey and United Kingdom (UK). Three banks in Turkey were involved; Kuveyt Turk katıtlım bank, 
Turkiye Finans katılım bank, and Albaraka katılım bank (Ziraat katılım Bank and Vakıf katılım bank were excluded as they were established recently). On the other hand, there were Five Islamic banks from UK; Al Rayan Bank, Bank of London and The Middle East (BLME), QIB UK, Gatehouse Bank, and Rasmala. More so, the method used is based on (CAMEL) ratios. To begin with and according to Hempel and Simonsos (1999), capital adequacy could be measured by equity/Total asset in order to show the capital strength. It can also be measured by the Average equity/ Average liabilities and this is according to Ansari and Rehman (2011), Iqbal (2001), and Hassan and Bashir (2003). Secondly, the asset quality which shows the financial strength, risk, and solvency ratio can be measured by Loans/ deposits. Thirdly, the Management quality could contain number of ratios for example Non int exp / avg asset. Fourthly, the operational ratio (earning diversification) according to Igbal (2001) and Hassan and Bashir (2003) can also be measured by many ratios; for example, this study will be a net interest margin. Fifthly, Liquidity ratio which shows the responses of the banks in needs of the liquid can be measured in this study either by Net loans / Total assets or liquid asset/ total asset. However, this liquidity has to be high in terms of capacity and it should be effortless (Sinkey \& Joseph, 2000). Last but not the least, profitability ratios were measured by return on average assets $(\mathrm{ROA})=$ Earnings after tax $/$ Average assets and Return on average equity (ROE); or return on average assets $($ ROA) $=$ Earnings after tax / Average equity (Sabi, 1996; Samad \& Hassan, 1999; Ansari \& Rehman, 2011; Bilal \& Amin, 2015).

\section{Pooled OLS Regression: (Panel Regression)}

According to Abdul Hadi et al. (2018), OLS is employed as a baseline analysis and it is used as an estimation model for this static panel data framework. Also, Ismal (2010) examined the impact of bank size (measured in total assets, total loans, and total deposits) on bank profit performance using OLS. Abedin and Dawan (2016) used OLS (a panel data analysis) to evaluate the profitability of the banking sector in Bangladesh.

PERFi, $t=$ ROAi t OR ROEi, PERF $i, t=\beta_{0}+\beta_{1}$ CAi $, t+\beta_{2} A Q i, t+\beta_{3} M Q i, t+\beta_{4} E D i, t+\beta_{5} L i, t+\varepsilon i, t$

Where:

PERF=performance

$\hat{i}=$ firm

$\boldsymbol{t}=$ time, year

ROA=Return on average asset

$\mathbf{R O E}=$ Return on average equity

$\mathbf{C A}=$ Capital adequacy

$\mathbf{A Q}=$ Asset quality (Risk and solvency)

MQ = Management quality

$\mathbf{E D}=$ Earning diversification (Operational)

$\mathbf{L}=$ Liquidity 
$\boldsymbol{\varepsilon}=$ Error term

Table 1

\begin{tabular}{|c|c|c|c|c|c|c|}
\hline $\begin{array}{c}\text { Capital } \\
\text { adequacy } \\
\text { ratio }\end{array}$ & $\begin{array}{c}\text { Capital } \\
\text { adequacy } \\
\text { ratio }\end{array}$ & $\begin{array}{c}\text { Risk and } \\
\text { solvency } \\
\text { ratio (asset } \\
\text { quality) }\end{array}$ & $\begin{array}{c}\text { Management } \\
\text { quality }\end{array}$ & $\begin{array}{c}\text { Operational } \\
\text { ratio (earning } \\
\text { diversification) }\end{array}$ & $\begin{array}{c}\text { Liquidity } \\
\text { ratio }\end{array}$ & $\begin{array}{c}\text { Liquidity } \\
\text { ratio }\end{array}$ \\
\hline $\begin{array}{c}\text { Equity / } \\
\text { Liabilities }\end{array}$ & $\begin{array}{c}\text { Equity / } \\
\text { total asset }\end{array}$ & $\begin{array}{c}\text { Loans/ } \\
\text { deposits }\end{array}$ & $\begin{array}{c}\text { Non int exp / } \\
\text { avg asset }\end{array}$ & $\begin{array}{c}\text { Net interest } \\
\text { margin }\end{array}$ & $\begin{array}{c}\text { Net loans / } \\
\text { Total assets }\end{array}$ & $\begin{array}{c}\text { liquid asset/ } \\
\text { total asset }\end{array}$ \\
\hline $\mathrm{C} 1$ & $\mathrm{C} 2$ & $\mathrm{~A}$ & $\mathrm{M}$ & $\mathrm{E}$ & $\mathrm{L} 1$ & $\mathrm{~L} 2$ \\
\hline
\end{tabular}

Table 1 showed the ratios and their abbreviation which was used in this study. The current study will measure these ratios and compare them to evaluate the financial performance of Islamic banks in Turkey and the UK.

\section{Results and Discussions}

All the result showed in Table 2 for UK is not significant because the $\mathrm{P}$-value is more than 0.05. At the same time, the coefficient between Asset quality and ROA is positive by 0.39 . It is also the same with Operational which is positive by 0.77 . On the other hand, Capital adequacy, Management quality, and liquidity are negative. We can see that adjusted R-squared is $-11 \%$ which is very low and this shows us that this type of model is not appropriate for this kind of data. Furthermore, within the same period, Turkey also used the same variables and the same test (Pooled OLS regression model). Table 3 showed that the P-value for asset quality is 0.007 and management quality is 0.024 . This means it is significant, however, that asset quality and management quality ratios affected ROA negatively. Thus, if they increase, the effect is opposite and ROA decreases. Moreover, others are not significant. And here adjusted R-squared is $85 \%$ which is much higher than in the UK.

Table 2. UK ROA (UK)

$\begin{array}{cr}\text { Variable } & \text { Coefficient } \\ \text { C1 } & -0.000934 \\ \text { A } & 0.398365 \\ \text { M } & -0.396808 \\ \text { E1 } & 0.774375 \\ \text { L2 } & -5.292695 \\ \text { C } & -1.280169 \\ \text { R }^{2} & 0.180590 \\ \text { Adjusted } \mathrm{R}^{2} & -0.112056\end{array}$


Table 3. Turkey

ROA (Turkey)

Variable

C1

A

M

E1

L1

$\mathrm{C}$

$\mathrm{R}^{2}$
Coefficient Std. Error Prob.

$\begin{array}{lll}0.078147 & 0.032122 & 0.0510\end{array}$

$\begin{array}{lll}-0.026755 & 0.006743 & 0.0074\end{array}$

$\begin{array}{lll}-0.401985 & 0.135150 & 0.0248\end{array}$

$\begin{array}{lll}0.232992 & 0.132918 & 0.1302\end{array}$

$\begin{array}{lll}0.023737 & 0.015996 & 0.1883\end{array}$

$\begin{array}{lll}1.521683 & 0.912327 & 0.1464\end{array}$

Adjusted $\mathrm{R}^{2}$

The results in Table 4 and 5 are similar to that of Table 2 and 3 . However, C2 was used instead of C1. For instance, the P-value for all the variables in UK is bigger than 0.05 and this means it is insignificant. Also, the adjusted R-squared is here is $-9 \%$ which is very low when compared with Turkey at $85 \%$. The result for Turkey is a bit different and the P-value for the two variables $\mathrm{A}=$ Risk and solvency ratio (asset quality) and $\mathrm{M}=$ management quality are less than 0.05 . This means that they are significant. Moreover, they have a negative coefficient correlation which is -0.026 for $\mathrm{A}$ and -0.392 for M.

Table 4. UK

\begin{tabular}{|c|c|c|c|}
\hline \multicolumn{4}{|c|}{ ROA (UK) } \\
\hline Variable & Coefficient & Std. Error & Prob. \\
\hline $\mathrm{C} 2$ & 0.017226 & 0.032289 & 0.6021 \\
\hline A & 1.242651 & 2.904168 & 0.6752 \\
\hline M & -1.242291 & 2.904962 & 0.6754 \\
\hline E1 & 0.988660 & 0.741405 & 0.2037 \\
\hline $\mathrm{L} 2$ & -5.418615 & 6.057506 & 0.3862 \\
\hline $\mathrm{C}$ & -2.171460 & 3.126970 & 0.4988 \\
\hline $\mathrm{R}^{2}$ & 0.193440 & & \\
\hline Adjusted $\mathrm{R}^{2}$ & -0.094617 & & \\
\hline
\end{tabular}

Table 5. Turkey

ROA (Turkey)

Variable

C2

A

M

E1

L1

C

$\mathrm{R}^{2}$

Adjusted R ${ }^{2}$

$\begin{array}{rrl}\text { Coefficient } & \text { Std. Error } & \text { Prob. } \\ 0.086978 & 0.036023 & 0.0523 \\ -0.026481 & 0.006758 & 0.0078 \\ -0.392726 & 0.137307 & 0.0288 \\ 0.226944 & 0.134551 & 0.1426 \\ 0.022993 & 0.016006 & 0.2009 \\ 1.548055 & 0.911755 & 0.1404\end{array}$

0.921697

0.856445 
Tables 6 and 7 show different results when the dependent variable was $\mathrm{ROE}=$ Return on average equity. The results show that all variables in UK were insignificant for Turkey except for one variable (A) which is significant when the P-value is 0.018 . This is less than 0.05 and at the same time, the coefficient was negatively correlated by -0.28 . Adjusted R-squared is higher for the UK by $7 \%$, but was very good for Turkey by $77 \%$.

Table 6. UK

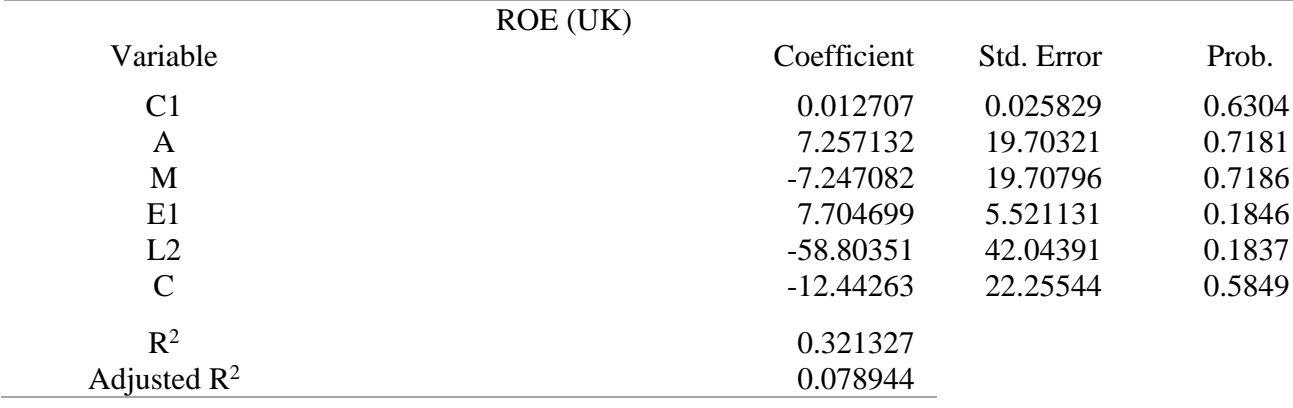

Table 7. Turkey

\begin{tabular}{|c|c|c|c|}
\hline \multicolumn{4}{|c|}{ ROE (Turkey) } \\
\hline Variable & Coefficient & Std. Error & Prob. \\
\hline $\mathrm{C} 1$ & -0.279818 & 0.426235 & 0.5359 \\
\hline A & -0.286816 & 0.089473 & 0.0185 \\
\hline M & -4.327718 & 1.793326 & 0.0523 \\
\hline E1 & 2.599754 & 1.763718 & 0.1909 \\
\hline L1 & 0.230604 & 0.212248 & 0.3190 \\
\hline $\mathrm{C}$ & 29.16491 & 12.10585 & 0.0526 \\
\hline $\mathrm{R}^{2}$ & 0.878399 & & \\
\hline Adjusted $\mathrm{R}^{2}$ & 0.777065 & & \\
\hline
\end{tabular}

In Tables 8 and 9, ROE is the dependent variable and the result in both countries are similar to the previous result, where UK variables are all insignificant with ROA and the adjusted R-squared is $19 \%$. On the other hand, for Turkey, just one variable is significant which is A by 0.017 as P-value is less than 0.05 . Also, the adjusted R-squared is $77 \%$ which shows that this model is appropriate for the data.

Table 8. UK

\begin{tabular}{|c|c|c|c|}
\hline \multicolumn{4}{|c|}{ ROE (UK) } \\
\hline Variable & Coefficient & Std. Error & Prob. \\
\hline $\mathrm{C} 2$ & 0.309513 & 0.207519 & 0.1580 \\
\hline A & 14.42850 & 18.66499 & 0.4524 \\
\hline M & -14.42891 & 18.67009 & 0.4525 \\
\hline E1 & 8.543691 & 4.764986 & 0.0946 \\
\hline L2 & -70.75831 & 38.93138 & 0.0906 \\
\hline $\mathrm{C}$ & -17.85534 & 20.09693 & 0.3893 \\
\hline $\mathrm{R}^{2}$ & 0.404256 & & \\
\hline Adjusted $\mathrm{R}^{2}$ & 0.191490 & & \\
\hline
\end{tabular}


Table 9. Turkey

ROE (Turkey)

$\begin{array}{crrl}\text { Variable } & \text { Coefficient } & \text { Std. Error } & \text { Prob. } \\ \text { C2 } & -0.331422 & 0.474092 & 0.5107 \\ \text { A } & -0.287500 & 0.088946 & 0.0179 \\ \text { M } & -4.392950 & 1.807075 & 0.0511 \\ \text { E1 } & 2.653273 & 1.770808 & 0.1847 \\ \text { L1 } & 0.231887 & 0.210659 & 0.3132 \\ \text { C } & 29.28178 & 11.99950 & 0.0505 \\ \text { R }^{2} & 0.879480 & & \\ \text { Adjusted } \mathrm{R}^{2} & 0.779048 & & \end{array}$

\section{Conclusion}

The last four decades have shown the increase of Islamic banks in the world economy in Muslim and non-Muslim countries. Few papers studied the performance of Islamic banks and compared them with conventional banks or with each other. Nevertheless, no study was founded about Islamic banks in the UK compared with Turkey.

The research used three Islamic banks from Turkey and five Islamic banks from the UK between 2013 to 2016 with 32 observations for UK (20) and Turkey (12).

From this result, we might not say that Islamic banks in Turkey are better than those in the UK. However, we might predict that Islamic banks in Turkey can perform better than Islamic banks in the UK in terms of risk and solvency and Management quality. However, this study has contributed to the literature by comparing the financial performance of Islamic banks in two different countries.

The main limitation of this study is small number of samples. The second limitation shows that the time period is small as well which ought to be a bit longer. It employs nine financial ratios divided into six board categories of profitability, Capital adequacy, Risk and solvency (asset quality), Management quality, Operational (earning diversification), and Liquidity.

The study recommended gives an opportunity for others to use other kind of financial performance ratios. Although the study was performed in two countries, future studies should be carried out on some number of banks and countries.

A seventh element can be added to CAMELS elements, which refer to Sharia compliant and later becomes SCAMELS. The integrity of Islamic banking transactions is closely linked to Shari'ah Supervisory Boards through an effective control over the Bank's transactions, as well as other elements of performance assessment of capital adequacy, assets, liquidity, and profitability. 


\section{References:}

1. Abdul Hadi, A. R., Hussain, H. I., Suryanto, T., \& Yap, T. H. (2018). Bank's performance and its determinants: evidence from Middle East, Indian sub-continent and African banks. Polish Journal of Management Studies, 17.

2. Abedin, M. T., \& Dawan, M. M. (2016). A Panel Data Analysis for Evaluating the Profitability of the Banking Sector in Bangladesh. Asian Journal of Economics and Empirical Research, 3(2), 163-171.

3. Amjad, M., Tahira, H., Akram, Y., \& Usman, M. (2013). Performance of Islamic and Conventional Banks in Pakistan (2006-2011), A comparatives study. IOSR Journal of Business and Management (IOSR-JBM), 63-76.

4. Ansari, S., \& Rehman, K. (2011). Comparative financial performance of existing Islamic Banks and contemporary conventional banks in Pakistan. In Proceedings 2nd International Conference on Economics, Business and Management.

5. Azhar Rosly, S., \& Afandi Abu Bakar, M. (2003). Performance of Islamic and mainstream banks in Malaysia. International Journal of Social Economics, 30(12), 1249-1265.

6. Bashir, A. H. M. (2001). Assessing the performance of Islamic banks: Some evidence from the Middle East. Topics in Middle Eastern and North African Economies, 3.

7. Bilal, M., \& Amin, H. (2015). Financial Performance of Islamic and Conventional Banks During and After US Sub-prime Crisis in Pakistan: A Comparative Study. Global Journal Al-Thaqafah, 5(2), 7387.

8. Brown, K. (2003). Islamic banking comparative analysis. The Arab Bank Review, 5(2), 43-50.

9. Dusuki, A. W. (2008). Understanding the objectives of Islamic banking: a survey of stakeholders' perspectives. International Journal of Islamic and Middle Eastern Finance and Management, 1(2), 132.

10. Haque, A., Jamil, O., \& Ahmad, Z. (2007, September). Islamic Banking: Customers Perception and its Prospect on Bank Product Selection towards Malaysian Customers Perspectives. In 5th International Islamic Finance Conference (pp. 3-4).

11. Hasan, M., \& Dridi, J. (2011). The effects of the global crisis on Islamic and conventional banks: A comparative study. Journal of International Commerce, Economics and Policy, 2(02), 163-200.

12. Hassan, M. K., \& Bashir, A. H. M. (2003, December). Determinants of Islamic banking profitability. In 10th ERF annual conference, Morocco (Vol. 7). 
13. Hawaldar, I. T., Rahiman, H. U., Rajesha, T. M., \& KR, N. K. (2017). A comparison of financial performance of Islamic and conventional banks in Bahrain. American Scientific Research Journal for Engineering, Technology, and Sciences (ASRJETS), 33(1), 100-110.

14. Hempel, G. H., \& Simonson, D. G. (1999). Bank Management, John Wiley\&Sons. Inc., New York.

15. Henry, C. M., \& Wilson, R. (Eds.). (2004). The politics of Islamic finance (p. 48). Edinburgh: Edinburgh University Press.

16. How, J. C., Karim, M. A., \& Verhoeven, P. (2005). Islamic financing and bank risks: the case of Malaysia. Thunderbird International Business Review, 47(1), 75-94

17. Ismal, R. (2010). The management of liquidity risk in Islamic Banks: the case of indonesia (Doctoral dissertation, Durham University).

18. Iqbal, M. (2001). Islamic conventional banking in the 1990s: A comparative study. Islamic Economic Studies, 8, 1-28.

19. Johnes, J., Izzeldin, M., \& Pappas, V. (2014). A comparison of performance of Islamic and conventional banks 2004-2009. Journal of Economic Behavior \& Organization, 103, S93-S107.

20. Kamil, W. A. R. (2014). Malaysia: World's Islamic Finance Marketplace. The Islamic Finance Handbook, 303-336.

21. Memon, N. A. (2007). Islamic banking: present and future challenges. Journal of Management and Social Sciences, 3(1), 1-10.

22. Mirakhor, A. (2000). General characteristics of an Islamic economic system. Anthology of Islamic banking, institute of Islamic banking and insurance, London, 11-31.

23. Rahman, A. R. A., \& Rosman, R. (2013). Efficiency of Islamic banks: A comparative analysis of MENA and Asian countries. Journal of Economic Cooperation \& Development, 34(1), 63.

24. Sabi, M. (1996). Comparative analysis of foreign and domestic bank operations in Hungary. Journal of comparative Economics, 22(2), 179188.

25. Samad, A., \& Hassan, M. K. (1999). The performance of Malaysian Islamic bank during 1984-1997: An exploratory study. International Journal of Islamic Financial Services, 1(3), 1-14.

26. Sehrish, S., Saleem, F., Yasir, M., Shehzad, F., \& Ahmed, K. (2012). Financial performance analysis of Islamic banks and conventional banks in Pakistan: A comparative study. Interdisciplinary Journal of Contemporary Research in Business, 4(5), 186-200.

27. Siddiqi, M. (2006). Islamic banking and finance in theory and practice: A survey of state of the art. Islamic Economic Studies, 13, 1-48. 
28. Sinkey Jr, J. F., \& Carter, D. A. (2000). Evidence on the financial characteristics of banks that do and do not use derivatives. The Quarterly Review of Economics and Finance, 40(4), 431-449.

29. Sundas Ayub, N. S., \& Mumtaz, R. (2012). Performance evaluation of Islamic and conventional banks in Pakistan. World Applied Sciences Journal, 20(2), 213-220.

30. Yildirim, I. (2015). Financial efficiency analysis in Islamic banks: Turkey and Malaysia models. Journal of Economics Finance and Accounting, 2(3).

\section{Appendix}

\section{Calculation details For England}

Dependent Variable: ROA

Method: Panel Least Squares

Date: 05/11/18 Time: 10:35

Sample: 20132016

Periods included: 4

Cross-sections included: 5

Total panel (balanced) observations: 20

\begin{tabular}{|c|c|c|c|c|}
\hline Variable & Coefficient & Std. Error & t-Statistic & Prob. \\
\hline $\mathrm{C} 1$ & -0.000934 & 0.003795 & -0.246167 & 0.8091 \\
\hline A & 0.398365 & 2.895095 & 0.137600 & 0.8925 \\
\hline M & -0.396808 & 2.895792 & -0.137029 & 0.8930 \\
\hline E1 & 0.774375 & 0.811248 & 0.954548 & 0.3560 \\
\hline L2 & -5.292695 & 6.177730 & -0.856738 & 0.4060 \\
\hline $\mathrm{C}$ & -1.280169 & 3.270108 & -0.391476 & 0.7013 \\
\hline R-squared & 0.180590 & \multicolumn{2}{|c|}{ Mean dependent var } & -0.699000 \\
\hline Adjusted R-squared & -0.112056 & \multicolumn{2}{|c|}{ S.D. dependent var } & 3.024387 \\
\hline S.E. of regression & 3.189339 & \multicolumn{2}{|c|}{ Akaike info criterion } & 5.400829 \\
\hline Sum squared resid & 142.4063 & \multicolumn{2}{|c|}{ Schwarz criterion } & 5.699549 \\
\hline Log likelihood & -48.00829 & \multicolumn{2}{|c|}{ Hannan-Quinn criter. } & 5.459143 \\
\hline F-statistic & 0.617094 & \multicolumn{2}{|c|}{ Durbin-Watson stat } & 1.159319 \\
\hline Prob(F-statistic) & 0.689052 & & & \\
\hline
\end{tabular}


Dependent Variable: ROA

Method: Panel Least Squares

Date: 05/11/18 Time: 10:35

Sample: 20132016

Periods included: 4

Cross-sections included: 5

Total panel (balanced) observations: 20

\begin{tabular}{ccrrr}
\hline \hline Variable & Coefficient & Std. Error & t-Statistic & Prob. \\
\hline \hline C2 & 0.017226 & 0.032289 & 0.6021 \\
A & 1.242651 & 2.904168 & 0.427885 \\
M & -1.242291 & 2.904962 & -0.427644 & 1.333494 \\
E1 & 0.988660 & 0.741405 & -0.894529 \\
L2 & -5.418615 & 6.057506 & -0.694429 & 0.2037 \\
C & -2.171460 & 3.126970 & 0.3862 \\
R-squared & 0.193440 & Mean dependent var & -0.699000 \\
Adjusted R-squared & -0.094617 & S.D. dependent var & 3.024387 \\
S.E. of regression & 3.164233 & Akaike info criterion & 5.385023 \\
Sum squared resid & 140.1732 & Schwarz criterion & 5.683743 \\
Log likelihood & -47.85023 & Hannan-Quinn criter. & 5.443336 \\
F-statistic & 0.671534 & Durbin-Watson stat & \\
Prob(F-statistic) & 0.651667 & & \\
\hline \hline
\end{tabular}

Dependent Variable: ROE

Method: Panel Least Squares

Date: 05/11/18 Time: 10:37

Sample: 20132016

Periods included: 4

Cross-sections included: 5

Total panel (balanced) observations: 20

\begin{tabular}{ccccc}
\hline \hline Variable & Coefficient & Std. Error & t-Statistic & Prob. \\
& & & \\
C1 & & & \\
A & 0.012707 & 0.025829 & 0.491969 & 0.6304 \\
M & 7.257132 & 19.70321 & 0.368322 & 0.7181 \\
E1 & -7.247082 & 19.70796 & -0.367724 & 0.7186 \\
L2 & 7.704699 & 5.521131 & 1.395493 & 0.1846 \\
C & -58.80351 & 42.04391 & -1.398621 & 0.1837 \\
& -12.44263 & 22.25544 & -0.559083 & 0.5849 \\
\hline R-squared & & & \\
Adjusted R-squared & & & \\
S.E. of regression & 0.321327 & Mean dependent var & -5.291000 \\
Sum squared resid & 0.078944 & S.D. dependent var & 22.61683 \\
Log likelihood & 21.70575 & Akaike info criterion & 9.236357 \\
F-statistic & 6595.955 & Schwarz criterion & 9.535076 \\
Prob(F-statistic) & -86.36357 & Hannan-Quinn criter. & 9.294670 \\
& 1.325697 & Durbin-Watson stat & 1.059210 \\
\hline \hline
\end{tabular}


Dependent Variable: ROE

Method: Panel Least Squares

Date: 05/11/18 Time: 10:38

Sample: 20132016

Periods included: 4

Cross-sections included: 5

Total panel (balanced) observations: 20

\begin{tabular}{|c|c|c|c|c|}
\hline Variable & Coefficient & Std. Error & t-Statistic & Prob. \\
\hline $\mathrm{C} 2$ & 0.309513 & 0.207519 & 1.491496 & 0.1580 \\
\hline A & 14.42850 & 18.66499 & 0.773025 & 0.4524 \\
\hline M & -14.42891 & 18.67009 & -0.772836 & 0.4525 \\
\hline E1 & 8.543691 & 4.764986 & 1.793015 & 0.0946 \\
\hline L2 & -70.75831 & 38.93138 & -1.817514 & 0.0906 \\
\hline $\mathrm{C}$ & -17.85534 & 20.09693 & -0.888461 & 0.3893 \\
\hline R-squared & 0.404256 & \multirow{7}{*}{\multicolumn{2}{|c|}{$\begin{array}{l}\text { Mean dependent var } \\
\text { S.D. dependent var } \\
\text { Akaike info criterion } \\
\text { Schwarz criterion } \\
\text { Hannan-Quinn criter. } \\
\text { Durbin-Watson stat }\end{array}$}} & -5.291000 \\
\hline Adjusted R-squared & 0.191490 & & & 22.61683 \\
\hline S.E. of regression & 20.33641 & & & 9.106028 \\
\hline Sum squared resid & 5789.976 & & & 9.404748 \\
\hline Log likelihood & -85.06028 & & & 9.164341 \\
\hline F-statistic & 1.900005 & & & 1.278031 \\
\hline Prob(F-statistic) & 0.158149 & & & \\
\hline
\end{tabular}

\section{For Turkey}

Dependent Variable: ROA

Method: Panel Least Squares

Date: 05/11/18 Time: 10:20

Sample: 20132016

Periods included: 4

Cross-sections included: 3

Total panel (balanced) observations: 12

\begin{tabular}{|c|c|c|c|c|}
\hline Variable & Coefficient & Std. Error & $\mathrm{t}$-Statistic & Prob. \\
\hline $\mathrm{C} 1$ & 0.078147 & 0.032122 & 2.432804 & 0.0510 \\
\hline A & -0.026755 & 0.006743 & -3.967880 & 0.0074 \\
\hline $\mathrm{M}$ & -0.401985 & 0.135150 & -2.974374 & 0.0248 \\
\hline E1 & 0.232992 & 0.132918 & 1.752896 & 0.1302 \\
\hline L1 & 0.023737 & 0.015996 & 1.483976 & 0.1883 \\
\hline $\mathrm{C}$ & 1.521683 & 0.912327 & 1.667913 & 0.1464 \\
\hline R-squared & 0.922279 & \multirow{7}{*}{\multicolumn{2}{|c|}{$\begin{array}{l}\text { Mean dependent var } \\
\text { S.D. dependent var } \\
\text { Akaike info criterion } \\
\text { Schwarz criterion } \\
\text { Hannan-Quinn criter. } \\
\text { Durbin-Watson stat }\end{array}$}} & 1.157500 \\
\hline Adjusted R-squared & 0.857512 & & & 0.283521 \\
\hline S.E. of regression & 0.107022 & & & -1.324703 \\
\hline Sum squared resid & 0.068723 & & & -1.082250 \\
\hline Log likelihood & 13.94822 & & & -1.414468 \\
\hline F-statistic & 14.23985 & & & 1.951455 \\
\hline Prob(F-statistic) & 0.002816 & & & \\
\hline
\end{tabular}


Dependent Variable: ROA

Method: Panel Least Squares

Date: 05/11/18 Time: 10:23

Sample: 20132016

Periods included: 4

Cross-sections included: 3

Total panel (balanced) observations: 12

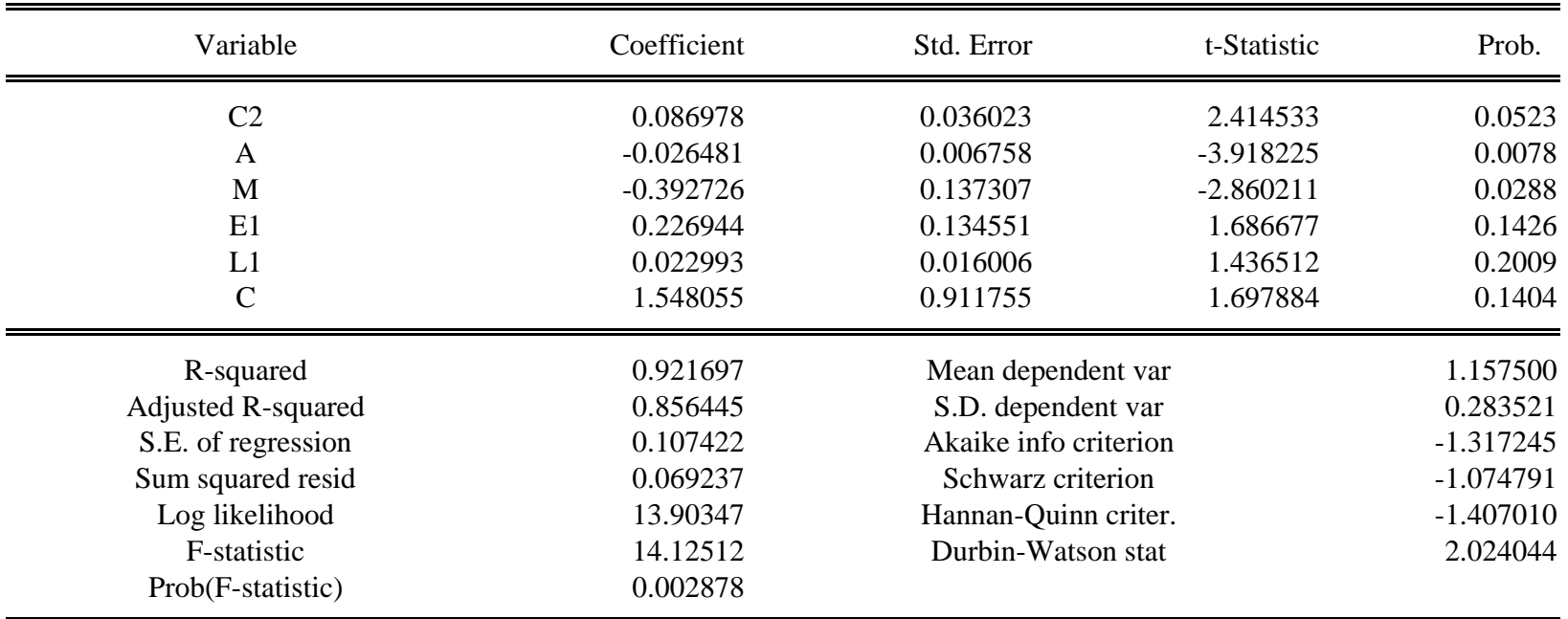

Dependent Variable: ROE

Method: Panel Least Squares

Date: 05/11/18 Time: 10:41

Sample: 20132016

Periods included: 4

Cross-sections included: 3

Total panel (balanced) observations: 12

\begin{tabular}{|c|c|c|c|c|}
\hline Variable & Coefficient & Std. Error & $\mathrm{t}$-Statistic & Prob. \\
\hline $\mathrm{C} 1$ & -0.279818 & 0.426235 & -0.656486 & 0.5359 \\
\hline A & -0.286816 & 0.089473 & -3.205604 & 0.0185 \\
\hline M & -4.327718 & 1.793326 & -2.413236 & 0.0523 \\
\hline E1 & 2.599754 & 1.763718 & 1.474018 & 0.1909 \\
\hline L1 & 0.230604 & 0.212248 & 1.086483 & 0.3190 \\
\hline $\mathrm{C}$ & 29.16491 & 12.10585 & 2.409158 & 0.0526 \\
\hline R-squared & 0.878399 & \multicolumn{2}{|c|}{ Mean dependent var } & 13.03167 \\
\hline Adjusted R-squared & 0.777065 & \multicolumn{2}{|c|}{ S.D. dependent var } & 3.007668 \\
\hline S.E. of regression & 1.420102 & \multicolumn{2}{|c|}{ Akaike info criterion } & 3.846187 \\
\hline Sum squared resid & 12.10014 & \multicolumn{2}{|c|}{ Schwarz criterion } & 4.088641 \\
\hline Log likelihood & -17.07712 & \multicolumn{2}{|c|}{ Hannan-Quinn criter. } & 3.756422 \\
\hline F-statistic & 8.668326 & \multicolumn{2}{|c|}{ Durbin-Watson stat } & 1.999079 \\
\hline $\operatorname{Prob}($ F-statistic) & 0.010226 & & & \\
\hline
\end{tabular}


Dependent Variable: ROE

Method: Panel Least Squares

Date: 05/11/18 Time: 10:41

Sample: 20132016

Periods included: 4

Cross-sections included: 3

Total panel (balanced) observations: 12

\begin{tabular}{|c|c|c|c|c|}
\hline Variable & Coefficient & Std. Error & t-Statistic & Prob. \\
\hline $\mathrm{C} 2$ & -0.331422 & 0.474092 & -0.699065 & 0.5107 \\
\hline A & -0.287500 & 0.088946 & -3.232296 & 0.0179 \\
\hline M & -4.392950 & 1.807075 & -2.430973 & 0.0511 \\
\hline E1 & 2.653273 & 1.770808 & 1.498341 & 0.1847 \\
\hline L1 & 0.231887 & 0.210659 & 1.100771 & 0.3132 \\
\hline $\mathrm{C}$ & 29.28178 & 11.99950 & 2.440250 & 0.0505 \\
\hline R-squared & 0.879480 & \multicolumn{2}{|c|}{ Mean dependent var } & 13.03167 \\
\hline Adjusted R-squared & 0.779048 & \multicolumn{2}{|c|}{ S.D. dependent var } & 3.007668 \\
\hline S.E. of regression & 1.413772 & \multicolumn{2}{|c|}{ Akaike info criterion } & 3.837252 \\
\hline Sum squared resid & 11.99251 & \multicolumn{2}{|c|}{ Schwarz criterion } & 4.079706 \\
\hline Log likelihood & -17.02351 & \multicolumn{2}{|c|}{ Hannan-Quinn criter. } & 3.747488 \\
\hline F-statistic & 8.756894 & \multicolumn{2}{|c|}{ Durbin-Watson stat } & 1.977927 \\
\hline Prob(F-statistic) & 0.009969 & & & \\
\hline
\end{tabular}

